\title{
Metaphor In English Version Of Sura Ali Imran
}

\begin{tabular}{|c|c|}
\hline & \\
\hline ARTICLE INFO & \multirow{13}{*}{$\begin{array}{l}\text { ABSTRACT } \\
\text { This paper intends to analyze one of them Sura in Al- } \\
\text { Qur'an. This study was conducted in Sura Ali Imran. The } \\
\text { source of the data was taken from the translation of Sura } \\
\text { Ali Imran. They were contained in the verses of Sura Ali } \\
\text { Imran, and then analyzed the kinds, functions, and the } \\
\text { reasons of using metaphor. The kinds are refers to Lakoff } \\
\text { and Johnson that divided the metaphor are arranged in } \\
\text { order according to which of Halliday's three } \\
\text { metafunctions. Then, the reason is based on Wahab's four } \\
\text { contextual reasons. Based on the data analysis, it was } \\
\text { found that there are two kinds of metaphor used in Sura } \\
\text { Ali Imran, } 5 \text { verses of explicit metaphor and } 10 \text { verses of } \\
\text { implicit metaphor. The second finding is there are } 9 \\
\text { functions used from } 13 \text { functions as the breakdown of } \\
\text { Halliday's three metafunction. The next finding found } \\
\text { that the reason why the metaphor is used in Sura Ali } \\
\text { Imran are because of four contextual reasons. Therefore, } \\
\text { it can be concluded that, some messages of the Al-Qur'an } \\
\text { in Sura Ali Imran have a stressing point which is } \\
\text { delivered in more beautiful words in implicit metaphor } \\
\text { that make the readers have a deeply understanding toward } \\
\text { the message. }\end{array}$} \\
\hline Article history: & \\
\hline Received March 28, 2019 & \\
\hline Revised May 02, 2019 & \\
\hline Accepted June 02, 2019 & \\
\hline Keywords: & \\
\hline Metaphor, & \\
\hline Sura Ali Imran, & \\
\hline Explicit, & \\
\hline Implicit & \\
\hline $\begin{array}{l}\text { Clonflict of Interest: } \\
\text { None }\end{array}$ & \\
\hline Funding: & \\
\hline None & \\
\hline
\end{tabular}

Corresponding Author: Ade Nurfitriani Harahap, Universitas Negeri Medan, adefitrihrp@gmail.com. Tel. $+6285370048427$

Copyright $\left({ }^{\circ}\right.$ Association of Language Teachers in Southeast Asia. All rights reserved

\section{Introduction}

Goatly (2005) states that metaphor is an essential topic in linguistic to be discussed. He says that the study of metaphor is important for two basic reasons. First, because consciously or not, people are employing metaphor all the time. And also because the working of metaphor sheds light on the ways in which literal language operates. In fact, if literal language is simply conventional metaphor, then far from being an anomaly, metaphor becomes basic. Seeing this reasons, it is interesting for language users to know what actually a metaphor is.

In the cognitive linguistic view, metaphor is defined as understanding one conceptual domain in terms of another conceptual domain. Examples of this include when the people talk and think about life in terms of journeys, about arguments in terms of war, about love also in terms of journeys, about theories in terms of buildings, about ideas in terms of food, about social organizations in terms of plants and many others. 
The metaphor is never introduced by an adjective such as 'similar', preposition such as 'to' or by a conjuction such as 'like' or 'as'. Where such occurs, the more explicit figure of speech is a called a simile. This simile, or figure of speech is also used extensively in every basic text.

Metaphor is neither natural nor universal but is culturally determined. It means that the study of the metaphor can be understood by the context of the metaphorically words or utterances them selves. Therefore, beside lexically determined, it is also important to understand the context of the metaphor. The kinds of metaphor is divided into two kinds they are explicit and implicit metaphor.

First of all, the person must understand or grasp an idea or concept. The person must also know of a second conceptor an experience. Finally there comes the expression of the direct comparison usually with the verb 'to be' in its various conjugated forms. Example, these (statements) are made pursuant to "safe harbor" provisions. It is implied that ConocoPhilips is a ship on a journey seeking a "safe harbor". The ship must overcome dangers and the environment so as to arrive safely.

There are two ways of recognising or regarding an implicit metaphor. The first method is the negative ways, the so-called proess of elimination and simply means that if a metaphor is recognised which is not an explicit one, it is therefore by exclusion, an implicit one. The second method requires a cognitive analysis either within or outside rhetoric to onclude that an attribute has been transferred from the source to the target. Example, "the lion gave a truly royal roar", its mean the people would have to already know extra-textually of a metaphor expressing the kingship of the lion or other part of speech.

The Al-Qur'an was the starting point for all the Islamic sciences, which were developed in order to study its grammar, pronunciation and style and it is the basis of Islamic law and theology; indeed, as the celebrated fifteenth-century scholar and author Suyuti said, 'Everything is based on the Al-Qur'an'. The Al-Qur'an is the supreme authority in Islam. It is the fundamental and paramount source of the creed, rituals, ethnics and laws of the Islamic religion. This supreme status stems from the belief that the Al-Qur'an is the word of God, revealed to the Prophet Muhammad via the archangel Gabriel and intended for all times and all places.

Ali Imran or The Family of Imran a Medinan Sura, which takes its title from the family of Imran, mentioned in verse 33. It begins by emphasizing that the Al-Qur'an confirms the earlier scriptures and goes on to say later than the central tenet of faith is devotion to God (verses 19-20). The story of Zachariah, Mary and Jesus is given in verses 35-64 and the fact that Jesus was unfathered, just as Adam was created without a father, is accentuated. Aspects of the battles of Badr and Uhud are described especially the latter where the Muslims disobeyed the Prophet and were defeated. The Sura first documents the tension that arose between the Muslims and certain of the other religions (verses 65-85 and 98101), then closes by emphasizing the unity of faith and conduct between the Muslims and some of these People of the Book explaining that these will have their reward from God (verse 199).

Like the preceding Surah, this one begins with the mention of divine revelation and men's reactions to it. In Al-Baqarah the main stress is laid on the contrasting attitudes of those who accept the truth revealed by God and those who reject it; the opening verses of AlImran, on the other hand, refer to the inclination of many misguided believers to interpret the allegorical passages of the Al-Qur'an and by implication, of the earlier revealed scriptures as well in an arbitrary manner, and thus to arrive at esoteric propositions which conflict with the true nature and purpose of the divine message. The Surah relates the story 
of Mary and Jesus, as well as of Zachariah, the father of John the Baptist, all of whom belonged to the Family of Imran.

Iqbal (1989) states that Al-Qur'an as one of the discourse will have its own contextual reason why it should be written on each different types of metaphor. Besides "Qur'an is book which emphasis deed rather than idea". This condition then leads the readers to really understand the meaning of the metaphors to apply the idea in the real life of people.

The findings of this study will be expected to enrich the research and analysis on AlQur'an studies. The research and analysis from of the kinds, functions and also reasons of the metaphor used in this Sura will help the reader understand more the meaning and interpretation of the Sura. This is also build the understandings of the readers on the studies of the language is Al-Qur'an which is special and unique as the word of God, Allah SWT.

\section{The Research Methodology}

\subsection{Research Design}

The research was conducted by using descriptive qualitative method. Qualitative research broadly defined means any kind of research that produces findings not arrived at by means of statistical procedures or other means of quantification (Strauss and Corbin, 1990).

\subsection{The Source of Data}

The source of data in this research is the translation of each verse in Sura Ali Imran from The Qur'an (Oxford World's Classic) published by Oxford University Press. Therefore the data were taken and analyzed from 200 verses written in Sura Ali Imran.

\subsection{The Instrument of Data Collection}

Based on the statement from Bogdan and Biklen (1992: 29) that is qualitative research has the natural setting as the direct source of the data and the reseracher is the key of instrument, the instrument in this research is the researcher herself.

\subsection{Technique of Data Collection}

The choice of the technique is qualitative research depends on the needs of the research. The technique of data collections in this research are shown; firstly, underlining and separating the metaphor from the verses which are retyped from The Qur'an by Haleem Abdel. Then, classifying the kinds of metaphor. Then, finding the reasons of the using in the kinds and functions.

\subsection{Technique of Data Analysis}

The data is analyzed by consulting to Ibnu Katsir's Tafseer contain of the explanation in Sura Ali Imran. According to Miles and Huberman (1994) the anaysis of qualitative data is organized arround three processes, they are:

1, Reducing Data, refers to the process of selecting, focusing, simplifying, abtracting and transforming field notes, transcriptions or other raw data. The researcher selected the data taken from each verses in Ali Imran which contain of metaphor.

2. Displaying Data, here the data was organized and compressed, so the researcher could see a large amount of data at once. This step is done after reducing the data, the researcher will separate the data based on its kinds and functions.

3. Drawing and Verifying Conclusion, in this process the researcher was trying to think about and decide what the data mean. After the data was separated, the final step was draw the conclusion of the data which had been classified from each kinds and functions to find the reasons why it should be like that according to the thory.

SALTeL Vol. 2, No. 2, July 2019: 56-62 


\section{The Results and Discussion}

\subsection{Explicit Metaphor in the Verse of Sura Ali Imran}

\section{Ali Imran (3): 4}

"Earlier as a guide for people and $\mathrm{He}$ has sent down the distinction [between right and wrong]. Those who deny God's revelations will suffer severe torment: God is almighty and capable of retribution."

In the verse 4 of Sura Ali Imran people can be find one metaphorical word. The word itself is distinction. It is a kind of explicit metaphor with a direct comparison with the words in the bracket. Therefore, we can grasp in the meaning of the distinction here as a difference between right and wrong.

\section{Ali Imran (3): 8}

"Our Lord do not let our hearts deviate after You have guided us. Grant us Your mercy: You are the Ever Giving."

The metaphorical word in the verse 8 of Sura Ali Imran is deviate. The word deviate here is directly compare with the next utterance have guided. It means deviate is unguidence by the Lord.

\section{Ali Imran (3): 15}

"[Prophet] say, "would you like me to tell you of things that are better than all of these?" Their Lord will give those who are mindful of God Gardens graced with flowing streams, where they will stay with pure spouses and God's good pleasure- God is fully aware of His servants."

In the verse 15 of Sura Ali Imran pure spouse is the metaphorical word given to the mindful man according to the verse. The word pure spouse means the pair of the mindful man, as the man has a wife and the woman has a husband but the difference is the pair is really pure from dishes and deseases.

\section{Ali Imran (3): 61}

"If anyone disputes this with you now that you have been given this knowledge, say, "Come, let us gather our sons and your sons, our women and your women, ourselves and yourselves and let us pray earnestly and invoke God's rejection on those of us who are lying."

The utterance pray earnestly here is the metaphorical utterance in this verse 61 of Sura Ali Imran. Pray earnestly in this verse show that the family of two sides should be serious and sincere in praying for the God to decide who is the true one.

\section{Ali Imran (3): 97}

"There are clear signs in it; it is the place where Abraham stood to pray; whoever enters it is safe. Pilgrimage to the House is a duty owed to God by people who are able to undertake it. Those who reject this [should know that] God has no need of anyone."

The word signs in this verse is describe by the next clause. The first sign is the place where Abraham stood to pray and the second is the place to pilgrimage. In this verse 97 of Sura Ali Imran the people categorize it as explicit metaphor.

\subsection{Implicit Metaphor in the Verse of Sura Ali Imran}

\section{Ali Imran (3): 21}

"Give news of agonizing torment to those who ignore God's revelations, who unjustifiably kill prophets, who kill those who command that justice is done." 
The kind of metaphor in verse 21 of Sura Ali Imran is implicit metaphor. The metaphorically word is justice that is not means the law and its administration in a court. Here, justice or the vehicle in this verse means hurt and humailiate punishment as the tenor of the vehicle.

\section{Ali Imran (3): 53}

"Lord, we believe in what You have revealed and we follow the messenger: record us among those who bear witness [to the Truth]."

The word witness here is the vehicle of the tenor the follower of the prophet Muhammad. Different with the usual meaning, the people who gives the evidence in a law court. Because of this situation, people call it as implicit metaphor.

\section{Ali Imran (3): 63}

"But if they turn away, then indeed - Allah is knowing of the corrupters."

Here, the meaning of corrupters is taking specially as immoral habit. In this verse it is not meant dishonest because of taking bribes.

\section{Ali Imran (3): 72}

"And a faction of the People of the Scripture say, at the beginning of the day, believe in what has been revealed to these believers [the Muslims], then at the end of the day reject it, so that they too may turn back."

The word utterance of it is the beginning of the day. This utterance is the vehicle of the verse to make us know that it means daybreak until noon.

\section{Ali Imran (3): 10}

"Neither their possessions nor their children will be any use to the disbelievers against God. The disbelievers will be fuel for the Fire."

The metaphor in the verse 10 of Sura Ali Imran is fuel. It is metaphorically meaningful. The word fuel is the vehicle of the sentence in which is understand as the things compared. People can understand it as the fire wood which is the tenor compared by the word fuel.

\section{Ali Imran (3): 13}

"You have already seen a sign in the two armies that met in battle, one fighting for God's cause and the other made up of disbelievers. With their own eyes [the former] saw [the latter] to be twice their number, but God helps whoever He will. There truly is a lesson in this for all with eyes to see"

The word eyes is the metaphor of the verse 13 in Sura Ali Imran. Here, the meaning of eyes is not the human body organs that the people found in human's face. The word eyes in this verse has a meaning as mind. In this case the word eyes is the vehicle. While the word mind is the tenor of the verse.

\section{Ali Imran (3): 77}

"But those who sell out God's covenant and their own oaths for a small price will have no share in the life to come. God will neither speak to them nor look at them on the Day of Resurrection - He will not cleanse them [of their sins] - agonizing torment awaits them."

The utterance sell out God's covenant and their own oaths for a small price in verse 77 of Sura Ali Imran is the implicit metaphor. The word price is the vehicle of this verse in which it means they change their own oaths only with world happiness.

8. Ali Imran (3): 64 
"Say, "people of the Book, let us arrive at a statement that is common to us all: we worship God alone, we ascribe no partner to Him, and none of us takes others beside God as lords." If they turn away, say, "witness our devotion to Him."”

The word statement in verse 64 of Sura Ali Imran is not a formal account of events. There is a metaphor here, in which the statement has a meaning as decision. Then become statement as a vehicle and decision as a tenor in this verse. The kinds of the metaphor here is implicit metaphor.

\section{Ali Imran (3): 48}

"He will teach him the Scripture and wisdom, the Torah and the Gospel"

This verse 48 of Sura Ali Imran has a metaphorical word, Scripture. Scripture here is refer to the ability of writing. The word scripture is the vehicle in this sentence while the ability of writing is the tenor. Because the Scripture can categorize it as implicit metaphor.

10. Ali Imran (3): 54

"The [disbelievers] schemed but God also schemed; God is the Best of Schemers."

The metaphorical word in the verse 54 of Sura Ali Imran is the schemer. In this verse, the schemer means The Creator (God) as a best tactictor. That is why the vehicle in this verse is schemer while the tenor is The Creator (God). Thus, this metaphor is classified as implicit metaphor.

Functions of the metaphor used in Sura Ali Imran are filling lexical gaps; reconceptualization; argument by analogy; ideology; decoration, disguise and hyperbole; cultivating intimacy; problem solving; textual structuring and enhancing memorability, foregrounding and informativeness.

The reason why the metaphor used in Sura Ali Imran are because of four contextual reasons. They are: 1) to explain the idea which is out of human life experience, 2) to explain an abstract thing concretely, 3) to explain something unknown yet with something familiar, and 4) to explain the idea about something untouchable to be as if it can be touched and felt.

Therefore, it can be concluded that some messages of the Al-Qur'an in Sura Ali Imran have a stressing point which is delivered in more beautiful words in implicit metaphor that nake the readers have a deeply understanding toward the message. The findings also show the rich of the language used in Al-Qur'an and the reality of the God's Law, Allah SWT, known from the functions which are not taken in this Sura.

After analyzing the data, it is clearly seen that there are some differences between the metaphor in Sura Ali Imran and the previous research, the metaphor in Sura Al-Baqarah. It is found in this research that the dominant kinds of metaphor used in Sura Ali Imran is implicit metaphor while the previous research. It means that some messages of the AlQur'an in Sura Ali Imran have a stressing point which is delivered in more beautiful words in implicit metaphor. As Halliday and Matthiessen (2004) states that the traditional approach to the metaphor is to look at it from below and ask what a certain expression means.

\section{Conclusion}

After data analysis was conducted in chapter IV, below are the conclusions:

1) There are 15 verses contain of metaphorical words and utterances in Sura Ali Imran. Those metaphorical words and utterances belong to two different kinds, they are explicit and implicit metaphor. 
2) There are several functions of metaphor as the construction of Halliday that is metafunction are used in Sura Ali Imran.

3) The reason why does the metaphor used in Sura Ali Imran is because of four contextual reasons as written in the previous chapter.

\section{Reference}

Bogdan, Robert C et al. 1992. Qualitative Research for Education. USA: Library of Congress Cataloging.

Gibbs, R. 1994. The poetics of mind: Figurative thought, language, and understanding. Cambridge, England: Cambridge University Press

Goatly, Andrew. 1998. Literal : The Language of Metaphor: New York: Routledge

Halliday, Matthiessen C. 2004. An Introduction to Functional Grammar: London: Routledge

Iqbal, M. 1989. The Reconstruction of Religious thought in Islam. Lahore: Iqbal Academy Pakistan

Johnson, M. 1987. The body in. the mind: The bodily basis of meaning, imagination, and reason. Chicago: University of Chicago Press

Johnson, M. 1993. Moral imagination: Implications of cognitive science for ethics. Chicago: University of Chicago Press

Johnson, M., (Ed.) 1981. Philosophical perspectives on metaphor. Minneapolis: University of Minnesota Press

Kovecses, Z. 1986. Metaphors anger, pride, and love: A lexical approach to the structure of concepts. Philadelphia: John Benjamins

Kovecses, Z. 2000. Metaphor and emotion: Language, culture, and body in hu- Ilan feeling. Cambridge. England: Cambridge University Press

Kovecses, Z. 2002. Metaphor: A practical introduction. New York: Oxford University Press

McNeill, D. 1992. Hand and mind: What gestures reveal about thought. Chicago: University of Chicago Press

Narayanan, S. 1997. Embodiment in language understanding: Sensory-motor representations for metaphoric reasoning about event descriptions. Unpublished doctoral dissertation, University of California, Berkeley

Strauss, A., \& Corbin, J. M. 1990. Basics of Qualitative Research: Grounded Theory Procedures and Techniques. Thousand Oaks, CA, US: Sage Publications, Inc

Stern, Josef. 2000. Metaphor in Context. USA: Massachusetts Institute of Technology

Sweetser, E. 1990. From etymology to pragmatics: Metaphorical and cultural aspects of semantic structure. Cambridge, England: Cambridge University Press 